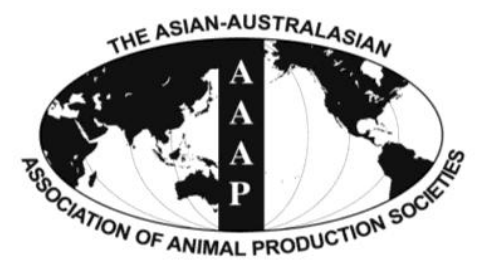

Asian-Aust. J. Anim. Sci.

Vol. 25, No. 12 : 1748-1758 December 2012

http://dx.doi.org/10.5713/ajas.2012.12298

www.ajas.info

pISSN 1011-2367 elSSN 1976-5517

\title{
Prediction of Digestible and Metabolizable Energy Content and Standardized Ileal Amino Acid Digestibility in Wheat Shorts and Red Dog for Growing Pigs
}

\author{
Q. Huang, X. S. Piao, P. Ren and D. F. Li* \\ Ministry of Agriculture Feed Industry Centre, State Key Laboratory of Animal Nutrition, \\ China Agricultural University, Beijing 100193, China
}

\begin{abstract}
Two experiments were conducted to evaluate the effects of chemical composition of wheat shorts and red dog on energy and amino acid digestibility in growing pigs and to establish prediction models to estimate their digestible (DE) and metabolizable (ME) energy content and as well as their standardized ileal digestible (SID) amino acid content. For Exp. 1, sixteen diets were fed to thirty-two growing pigs according to a completely randomized design during three successive periods. The basal diet was based on corn and soybean meal while the other fifteen diets contained $28.8 \%$ wheat shorts $(\mathrm{N}=7)$ or red $\operatorname{dog}(\mathrm{N}=8)$, added at the expense of corn and soybean meal. Over the three periods, each diet was fed to six pigs with each diet being fed to two pigs during each period. The apparent total tract digestibility (ATTD) of energy in wheat shorts and red dog averaged 75.1 and $87.9 \%$. The DE values of wheat shorts and red dog averaged $13.8 \mathrm{MJ} / \mathrm{kg}$ (range 13.1 to $15.0 \mathrm{MJ} / \mathrm{kg}$ ) and $15.1 \mathrm{MJ} / \mathrm{kg}$ (range 13.3 to $16.6 \mathrm{MJ} / \mathrm{kg}$ ) of dry matter, respectively. For Exp. 2, twelve growing pigs were allotted to two $6 \times 6$ Latin Square Designs with six periods. Ten of the diets were formulated based on $60 \%$ wheat shorts or red dog and the remaining two diets were nitrogen-free diets based on cornstarch and sucrose. Chromic oxide (0.3\%) was used as an indigestible marker in all diets. There were no differences ( $p>0.05)$ in SID values for the amino acids in wheat shorts and red dog except for lysine and methionine. Apparent ileal digestibility (AID) and SID values for lysine in different sources of wheat shorts or red dog, which averaged 78.1 and $87.8 \%$, showed more variation than either methionine or tryptophan. A stepwise regression was performed to establish DE, ME and amino acid digestibility prediction models. Data indicated that fiber content and amino acid concentrations were good indicators to predict energy values and amino acid digestibility, respectively. The present study confirms the large variation in the energy content and amino acid digestibility in wheat shorts and red dog, and describes the factors that influence this variation and presents equations based on chemical composition that could probably be used to predict the DE and ME values as well as the amino acid digestibility of wheat shorts and red dog. (Key Words: Prediction, Digestibility, Growing Pigs, Wheat Shorts, Red Dog)
\end{abstract}

\section{INTRODUCTION}

Wheat shorts and red dog are by-products of the wheat milling industry produced when wheat is processed into flour for human consumption and are often used as feed ingredients in the commercial feed industry (Blasi et al., 1998). These two wheat milling by-products both consist of fine particles of wheat bran, wheat germ, wheat flour, and the offal from the "tail of the mill" (AAFCO, 1996). However, the different combination and concentrations of different fractions among these by-products can lead to the

\footnotetext{
* Corresponding Author: D. F. Li. Tel: +8610-6273-3588, Fax: +8610-6273-3688, E-mail: defali@public2.bta.net.cn Submitted May 29, 2012; Accepted Aug. 11, 2012; Revised Aug. 28, 2012
}

variability of the chemical compositions of the end products.

There is growing demand for wheat shorts and red dog as an ingredient in swine diet formulation (Slominski et al., 2004). The inclusion of wheat shorts has been recommended at levels up to $30 \%$ of the diet (Holden and Zimmerman, 1991) as they provide a good source of energy, amino acids, and phosphorus for growing-finishing pigs (Erickson et al., 1985). However, a problem associated with the use of wheat shorts and red dog in diets for growing pigs is their lack of uniformity due to variable proportions of endosperm and bran particles (Huang et al., 1999). The nutrient content of wheat shorts and red dog depends on the physical properties of the original wheat used to produce them, the milling operation, and the end products desired (Blasi et al., 1998). 
Few experiments have been conducted to evaluate the nutritional value of wheat milling by-products for pigs (Sauer et al., 1977; Erickson et al., 1985; Huang et al., 1999; 2001). Savant et al. (2004) recommended using chemical composition to predict the energy values of wheat milling by-products. Subsequently, Wan et al. (2009) developed models to predict energy values in wheat milling by-products (wheat bran, wheat middlings, wheat shorts and red dog) when fed to ducks. However, similar experiments have not been conducted with swine. Therefore, this study was conducted to measure the chemical composition of wheat shorts and red dog and determine their energy and amino acid digestibility using growing pigs. These values were then utilized to establish prediction models to estimate the energy content and amino acid digestibility of samples of wheat shorts and red dog.

\section{MATERIALS AND METHODS}

\section{General}

The Institutional Animal Care and Use Committee at China Agricultural University (Beijing, China) reviewed and approved the protocols used in the study. Seven samples of wheat shorts and 8 samples of red dog were collected from 10 provinces in China involving 15 separate wheat flour mills. Samples were taken, ground through a 1 $\mathrm{mm}$ screen, and then stored for further analysis. The chemical composition and source of the wheat shorts and red dog are shown in Table 1.

\section{Experimental design}

Exp. 1 was conducted to determine the energy values of wheat shorts and red dog. Previous studies have recommended dietary inclusion levels of 20 to $40 \%$ wheat milling by-products in swine diets (Cromwell et al., 2000; Le Goff and Noblet, 2001). Therefore, a preliminary experiment was conducted using $19.2,28.8$, or $38.4 \%$ wheat shorts or red dog in the diet to monitor pig performance and
Table 2. Ingredient of composition of experimental diets (Exp. $1, \%$ as fed)

\begin{tabular}{lcc}
\hline Ingredient $(\%)$ & Basal diet & $\begin{array}{c}\text { Wheat shorts or } \\
\text { red dog diets }\end{array}$ \\
\hline Corn & 71.52 & 50.06 \\
Soybean meal & 24.20 & 16.94 \\
Wheat shorts or red dog & - & 28.80 \\
L-lysine-HCl, 98\% & 0.28 & 0.20 \\
Dicalcium phosphate $_{\text {Calcium carbonate }}^{1.40}$ & 0.90 & 1.40 \\
Wheat rice stone $^{1}$ & 0.80 & 0.90 \\
Sodium chloride $^{\text {Vitamin-mineral premix }}{ }^{2}$ & 0.40 & 0.80 \\
& 0.50 & 0.40 \\
\hline
\end{tabular}

${ }^{1}$ Used as carrier for L-lysine $\mathrm{HCl}$ and contained more than $70 \%$ silicon oxide and aluminium oxide, made by YiXian BeiQiaoTou Ore Company Limited, Hebei, China.

${ }^{2}$ Provided the following per kilogram of diet: $\mathrm{Mn}, 50 \mathrm{mg}$ as $\mathrm{MnO} ; \mathrm{Fe}, 125$ $\mathrm{mg}$ as $\mathrm{FeSO}_{4} \cdot \mathrm{H}_{2} \mathrm{O} ; \mathrm{Zn}, 125 \mathrm{mg}$ as $\mathrm{ZnO} ; \mathrm{Cu}, 150 \mathrm{mg}$ as $\mathrm{CuSO}_{4} \cdot 5 \mathrm{H}_{2} \mathrm{O}$; I, $50 \mathrm{mg}$ as $\mathrm{CaI}_{2} ; \mathrm{Se}, 0.48 \mathrm{mg}$ as $\mathrm{Na}_{2} \mathrm{SeO}_{3}$, retinyl acetate, 4,500 IU; cholecalciferol, 1,350 IU; DL- $\alpha$ - tocopheryl acetate, $13.5 \mathrm{mg}$; menadione sodium bisulfite complex, $2.7 \mathrm{mg}$; niacin, $18 \mathrm{mg}$; vitamin $\mathrm{B}_{12}, 27.6 \mu \mathrm{g}$; thiamine, $0.6 \mathrm{mg}$; pyridoxine, $0.9 \mathrm{mg}$; riboflavin, $1.8 \mathrm{mg}$; D-capantothenate, $10.8 \mathrm{mg}$; nicotinic acid, $30.3 \mathrm{mg}$; choline chloride, $210 \mathrm{mg}$.

the results of this experiment indicated that the optimal inclusion rate was $28.8 \%$ (data are not shown). Therefore, this inclusion level was chosen for use in Exp. 1.

In Exp. 1, sixteen diets were fed to thirty-two crossbred (Duroc $\times$ Landrace $\times$ Yorkshire) barrows (initial BW, 35.8土 $3.2 \mathrm{~kg}$ ) according to a completely randomized design. The basal diet was based on corn and soybean meal while the other fifteen diets contained $28.8 \%$ wheat shorts or red dog added at the expense of corn and soybean meal. The basal diet with no addition of wheat by-products was formulated to allow for calculation of the DE and ME content of the fifteen samples of wheat shorts or red dog using the difference method (Adeola, 2001). All ingredients were ground through a $2.5-\mathrm{mm}$ screen (hammer mill). The ingredient composition of the diets used in the study is presented in Table 2 .

Table 1. Chemical composition of fifteen samples of wheat shorts and red dog used in experiment $1(\% \mathrm{DM})^{1}$

\begin{tabular}{|c|c|c|c|c|c|c|c|c|c|c|c|c|c|c|c|c|c|c|c|}
\hline \multirow{2}{*}{ Item $(\%)$} & \multicolumn{8}{|c|}{ Wheat red dog } & \multirow{2}{*}{ Mean } & \multirow{2}{*}{$\mathrm{CV}^{2}$} & \multicolumn{7}{|c|}{ Wheat shorts } & \multirow{2}{*}{ Mean } & \multirow{2}{*}{$\mathrm{CV}$} \\
\hline & $\mathrm{HEN}^{\mathrm{a}}$ & $\mathrm{HEN}^{\mathrm{c}}$ & $\mathrm{HEB}^{\mathrm{a}}$ & $\mathrm{LN}$ & SX & $\mathrm{HEN}^{\mathrm{d}}$ & $\mathrm{XJ}$ & $\mathrm{JS}^{\mathrm{b}}$ & & & GS & $\mathrm{SC}$ & $\mathrm{HEN}^{\mathrm{b}}$ & HUB & FJ & $\mathrm{HEB}^{\mathrm{b}}$ & $\mathrm{JS}^{\mathrm{a}}$ & & \\
\hline $\mathrm{CP}$ & 15.05 & 14.16 & 14.70 & 13.95 & 16.14 & 17.78 & 16.40 & 16.81 & 15.62 & 8.74 & 17.76 & 15.43 & 19.41 & 18.42 & 20.36 & 17.53 & 17.02 & 17.95 & 8.77 \\
\hline Ether & 2.25 & 1.73 & 2.39 & 2.48 & 2.60 & 3.64 & 3.36 & 3.08 & 2.69 & 23.34 & 3.65 & 2.54 & 3.98 & 2.23 & 4.70 & 4.93 & 4.03 & 3.72 & 27.32 \\
\hline & 7.80 & 6.18 & 9.37 & 11.11 & 16.66 & 15.04 & 20.79 & 19.91 & 13.36 & 41.52 & 29.62 & 21.21 & 25.58 & 26.68 & 24.35 & 28.97 & 30.38 & 26.68 & 12.25 \\
\hline & 2.22 & 1.44 & 1.60 & 2.31 & 3.54 & 4.22 & 4.49 & 5.17 & 3.12 & 45.38 & 6.68 & 4.80 & 5.73 & 3.81 & 6.87 & 7.98 & 8.66 & 6.36 & 26.93 \\
\hline & 81.31 & 79.16 & 61.29 & 68.16 & 58.88 & 60.26 & 44.30 & 47.26 & 62.58 & 21.32 & 48.62 & 44.22 & 42.12 & 40.31 & 39.83 & 26.65 & 35.36 & 39.59 & 17.72 \\
\hline & 1.33 & 1.70 & 1.98 & 2.55 & 2.92 & 3.16 & 4.34 & 4.64 & 2.83 & 42.27 & 4.91 & 5.04 & 5.12 & 6.75 & 6.89 & 7.23 & 7.66 & 6.23 & 18.70 \\
\hline & 22 & 3.44 & 2.66 & 3.87 & 3.35 & 4.89 & 8.26 & & 3.82 & 53.22 & 10.54 & 7.14 & 10.36 & 9.95 & 9.81 & 8.42 & 8.45 & 9.24 & 13.61 \\
\hline Ash & 1.30 & 0.93 & 1.50 & 1.34 & 1.86 & 2.09 & 3.01 & 2.74 & 1.85 & 39.52 & 3.12 & 2.48 & 2.84 & 3.97 & 3.81 & 4.56 & 3.78 & 3.51 & 20.61 \\
\hline & 0.03 & 0.02 & 0.03 & 0.02 & 0.06 & 0.03 & 0.09 & 0.07 & 0.04 & 59.78 & 0.08 & 0.06 & 0.07 & 0.06 & 0.07 & 0.08 & 0.08 & 0.07 & 12.60 \\
\hline Phosphorus & 0.29 & 0.23 & 0.22 & 0.27 & 0.32 & 0.37 & 0.53 & 0.46 & 0.34 & 31.32 & 0.41 & 0.45 & 0.52 & 0.71 & 0.74 & 0.77 & 0.68 & 0.61 & 24.17 \\
\hline
\end{tabular}

${ }^{\text {abcd }}$ Samples from different flour mills in a province.

${ }^{1} 15$ samples from 15 wheat flour mills in 10 provinces $(\mathrm{HEN}=$ He'nan, HEB = Hebei, LN = Liaoning, SX = Shanxi, XJ = Xinjiang, JS = Jiangsu, GS = Gansu, SC = Sichuan, FJ = Fujian, HUB = Hubei).

${ }^{2} \mathrm{CV}=$ Coefficient of variation. 
The thirty-two crossbred pigs were individually housed in stainless steel metabolism cages $\left(1.4 \times 0.45 \times 0.6 \mathrm{~m}^{3}\right)$. The 32 pigs were assigned to the sixteen treatments in three successive replicates of 16 pigs ( 2 pigs per treatment). Over the three periods, each diet was fed to six pigs with each diet being fed to two pigs during each period. Each period lasted $12 \mathrm{~d}$ comprised of a $7 \mathrm{~d}$ adaptation period followed by a $5 \mathrm{~d}$ total collection of feces and urine.

Pigs were weighed at the beginning of each period. The diets were provided at a rate of $4 \%$ of the average BW determined at the initiation of each adaptation period. The daily feed allowance was divided into two equal meals fed at 08:00 and 17:00 h. Water was freely available from a low-pressure drinking nipple. The diets were all provided in mash form.

Before the initiation of Exp. 2, an experiment was conducted to determine what percentage of wheat shorts and red dog the pigs would tolerate in their diets. There were some comparative studies (Fan and Sauer, 1995a, b) in which the effects of direct and difference methods on AID values were compared, and no major impact on the determinations of AID values were found. Also, no differences were also observed between SID values in the study of Fan and Sauer (1995a) and Eklund (2008), either determined according to the direct and regression analysis method. To decrease the risk of error and interactions by difference method, wheat shorts or red dog were fed to pigs directly as the sole protein source in the diet and $60 \%$ percentage was the level chosen for future use (data are not shown).

In Exp. 2, ten samples of wheat shorts or red dog were chosen to determine the ileal digestibility of amino acids according to the maximum variance of amino acids content distribution in samples. Ten diets were formulated consisting of $60.0 \%$ wheat shorts or red dog, $24.30 \%$ cornstarch, $10.0 \%$ sucrose, $2.0 \%$ soybean oil and $3.7 \%$ vitamins and minerals added to meet or exceed the estimated nutrient requirements for growing pigs with the exception of amino acids (NRC, 1998). A nitrogen-free diet was used to determine the basal ileal endogenous nitrogen losses. Chromic oxide $(0.3 \%)$ was added into all of the diets as the inert marker. Potassium carbonate and magnesium oxide were included in the nitrogen-free diet to meet the pig's mineral requirements. Soybean oil was included at a level $3 \%$ to reduce dustiness and increase the energy density of the diets.

For Exp. 2, twelve crossbred (Duroc $\times$ Landracex Yorkshire) barrows (initial BW, $35.1 \pm 2.5 \mathrm{~kg}$ ) were fitted with a simple T-cannula at the distal ileum using procedures described by Stein et al. (1998) and allotted to two $6 \times 6$ Latin square design with 6 periods and 12 diets. During a 14-d period, a nutritionally balanced commercial diet was provided to the pigs. Each experimental period lasted $9 \mathrm{~d}$.
Following a 5-d adaptation period, digesta was collected for a 2-d experimental period (08:00 to 16:00). After each collection period, the pigs were fed a commercial diet for two days to recover.

For Exp. 1, after an adaptation period of $7 \mathrm{~d}$, a total collection of feces and urine was conducted for five successive days following the methods described by Song et al. (2003). Feed refusals and spillage were collected daily and analyzed for DM content. Feces were collected immediately as feces appeared in the metabolism crates and placed in plastic bags to be stored at $-20^{\circ} \mathrm{C}$. Urine was collected in a bucket placed under the metabolic crate. The bucket contained $10 \mathrm{ml}$ of $6 \mathrm{~N} \mathrm{HCl}$ for every $1,000 \mathrm{ml}$ of urine. Each day, the total urine volume was measured and a $10 \%$ aliquot was filtered through gauze and $50 \mathrm{ml}$ of the mixed urine samples were transferred into a screw-capped tube and stored immediately at $-20^{\circ} \mathrm{C}$ until needed for analysis. At the end of the collection period, feces were thawed, pooled by pig within period, homogenized, subsampled, dried $72 \mathrm{~h}$ in a $65^{\circ} \mathrm{C}$ drying oven and ground through a 1-mm screen.

For Exp. 2, Digesta was collected in plastic bags attached to the simple T-cannula until the bag was full and stored in a $-20^{\circ} \mathrm{C}$ freezer immediately after each collection. Ileal digesta samples were thawed, mixed within animal and diet, and a sub-sample was taken. Digesta samples were lyophilized in a vacuum-freeze dryer (Tofflon Freezing Drying Systems, Minhang District, Shanghai, China) and ground through a 1-mm screen for further chemical analysis.

\section{Chemical analyses}

$\mathrm{DM}$, ether extract (EE), CP $(\mathrm{N} \times 6.25)$, ash, $\mathrm{CF}, \mathrm{NDF}$, $\mathrm{ADF}, \mathrm{Ca}$ and $\mathrm{P}$ content in diets and wheat shorts and red dog were analyzed according to the procedures of the Association of Official Analytical Chemists (AOAC, 2000). The gross energy (GE) of feces, diets and wheat shorts and red dog samples were measured using an automatic adiabatic oxygen bomb calorimeter (Parr 6300 Calorimeter, Moline, IL). The gross energy (GE) of urine was injected 4 $\mathrm{ml}$ sample into 2 filter papers in a special crucible, and dried $8 \mathrm{~h}$ in $65^{\circ} \mathrm{C}$ drying oven to determine the energy. Wheat shorts and red dog samples were hydrolyzed with 11 $\mathrm{N}$ sulfuric acid at $128^{\circ} \mathrm{C}$ for $3 \mathrm{~h}$ and an Ion Chromatograph (Dionex ICS-3000, Sunnyvale, CA, USA) was then used to analyze xylans. Starch content was determined after converting starch to glucose using an enzyme assay kit (Megazym International Ireland, Wicklow, Ireland). Wheat shorts and red dog, diets, digesta were hydrolyzed with $6 \mathrm{~N}$ $\mathrm{HCl}$ at $110^{\circ} \mathrm{C}$ for $24 \mathrm{~h}$ and analyzed for 15 amino acids using an Amino Acid Analyzer (Hitachi L-8900, Tokyo, Japan). Methionine and cystine were determined as methionine sulfone and cysteic acid after cold performic acid oxidation overnight and hydrolyzing with $7.5 \mathrm{~N} \mathrm{HCl}$ at 
$110^{\circ} \mathrm{C}$ for $24 \mathrm{~h}$ using an Amino Acid Analyzer (Hitachi L8800, Tokyo, Japan). Tryptophan was determined after $\mathrm{LiOH}$ hydrolysis for $22 \mathrm{~h}$ at $110^{\circ} \mathrm{C}$ using HPLC (Agilent 1200 Series, Santa Clara, CA, USA). The chromium concentration of diets and ileal digesta samples were determined after nitric acid-perchloric acid wet ash sample preparation using Polarized Zeeman Atomic Absorption Spectrometer (Hitachi Z2000, Tokyo, Japan).

\section{Calculations and statistical analyses}

In Exp. 1, the DE and ME values contributed by each samples were calculated according to difference method (Adeola, 2001) by subtracting the DE and ME values contributed by the basal energy contributing ingredients.

In Exp. 2, the AID for the amino acids in the diets containing wheat shorts and red dog were calculated using the equations described by Stein et al. (2007):

$$
\mathrm{AID}=(1-(\mathrm{AAd} / \mathrm{AAf}) \times(\mathrm{Crf} / \mathrm{Crd})) \times 100 \%
$$

where AAd is the concentration of amino acids in the ileal digesta $(\mathrm{g} / \mathrm{kg}$ of $\mathrm{DM})$, AAf is the concentration of amino acids in the diets $(\mathrm{g} / \mathrm{kg}$ of $\mathrm{DM}), \mathrm{Crf}$ represents chromium concentration in the diet $(\mathrm{g} / \mathrm{kg}$ of $\mathrm{DM})$, and Crd represents in the digesta $(\mathrm{g} / \mathrm{kg}$ of $\mathrm{DM})$. The AID for $\mathrm{CP}$ was also calculated by using this equation where amino acids are replaced by the concentration of the $\mathrm{CP}$ in the digesta and diets.

The basal endogenous loss of each amino acid $\left(\mathrm{IAA}_{\text {end }}\right.$, $\mathrm{g} / \mathrm{kg}$ of DMI) at the distal ileum was determined based on the outflow obtained when pigs were fed the N-free diet using the equation of Stein et al. (2007):

$$
\mathrm{IAA}_{\text {end }}=(\mathrm{AAd} \times(\mathrm{Crf} / \mathrm{Crd})) \times 100 \%
$$

where AAd is the concentration of each amino acid in the ileal digesta collected from pigs fed the N-free diet. The endogenous outflow of CP was determined using the same equation where AAd is replaced by the concentration of the $\mathrm{CP}$ in the digesta.

By correcting the AID of each amino acid that was calculated for each sample for the IAA $_{\text {end }}$ of each amino acid, the SID of each amino acid was calculated using the equation of Stein et al. (2007):

$$
\mathrm{SID}=\left(\mathrm{AID}+\left(\mathrm{IAA}_{\text {end }} / \mathrm{AA}_{\text {diet }}\right) \times 100 \%\right)
$$

\section{Statistical analysis}

The linear equations for predicting the DE, ME and ileal amino acid digestibility of samples from chemical composition were obtained using the stepwise regression procedure with SAS (SAS Inst. Inc., Cary, NC). The sources of wheat shorts and red dog in experiments were compared using a general linear model with wheat shorts and red dog, pig, and period as the main effects. If significant differences were found, the Student Newman Keul's test was used to test the significance of differences between means. The contrast option of SAS was used to compare energy values and amino acid digestibility of wheat shorts and red dog. The level of significance adopted was $1 \%(\mathrm{p}<0.01)$. The equations with the smallest residual standard deviation (RSD) are presented in the results.

\section{RESULTS}

\section{Chemical composition of wheat shorts and red dog}

There were seventeen samples collected in total, fifteen samples for Exp. 1 and ten samples for Exp. 2, in such, eight samples were used in both Exp. 1 and 2 .

The collected wheat shorts and red dog samples varied widely in chemical composition (Tables 1 and 6). From these two tables, we could see that, NDF concentration in wheat shorts ranged from 21.21 to $30.38 \%$ (mean $26.12 \%$ ) of DM and red dog from 6.18 to $20.79 \%$ (mean $13.33 \%$ ) of $\mathrm{DM}$, while values of ADF in wheat shorts ranged from 3.77 to $8.66 \%$ (mean $6.00 \%$ ) of DM and red dog from 1.40 to 5 . $17 \%$ (mean $2.76 \%$ ) of DM, showing more variation than most other non-fiber nutrients.

As to amino acid content in ten samples of wheat shorts and red dog, the values of lysine ranged from 0.31 to $0.66 \%$, with a mean value of $0.49 \%$. Concentrations of methionine

\begin{tabular}{|c|c|c|c|c|c|c|c|c|c|c|c|c|c|c|c|c|c|c|c|c|}
\hline \multirow{2}{*}{$\begin{array}{r}\text { Item } \\
(\%)\end{array}$} & \multirow{2}{*}{$\begin{array}{c}\text { Basal } \\
\text { diet }\end{array}$} & \multicolumn{8}{|c|}{ Wheat red dog diets } & \multirow{2}{*}{ Mean } & \multirow{2}{*}{$\mathrm{CV}^{2}$} & \multicolumn{7}{|c|}{ Wheat shorts diets } & \multirow{2}{*}{ Mean } & \multirow{2}{*}{$\mathrm{CV}$} \\
\hline & & $\mathrm{HEN}^{\mathrm{a}}$ & $\mathrm{HEN}^{\mathrm{c}}$ & $\mathrm{HEB}^{\mathrm{a}}$ & LN & SX & $\mathrm{HEN}^{\mathrm{d}}$ & XJ & $\mathrm{JS}^{\mathrm{b}}$ & & & GS & $\mathrm{SC}$ & $\mathrm{HEN}^{\mathrm{b}}$ & HUB & FJ & $\mathrm{HEB}^{\mathrm{b}}$ & $\mathrm{JS}^{\mathrm{a}}$ & & \\
\hline $\mathrm{CP}$ & 19.39 & 18.59 & 19.61 & 18.75 & 17.32 & 19.51 & 18.29 & 19.85 & 19.87 & 18.97 & 4.73 & 20.74 & 18.69 & 19.96 & 24.23 & 22.34 & 19.61 & 20.60 & 20.88 & 8.90 \\
\hline $\mathrm{EE}$ & 1.84 & 1.38 & 2.13 & 1.57 & 2.13 & 1.53 & 1.70 & 2.44 & 3.35 & 2.03 & 31.97 & 2.52 & 2.21 & 1.98 & 2.26 & 2.38 & 2.77 & 2.52 & 2.38 & 10.72 \\
\hline NDF & 15.28 & 13.47 & 14.56 & 14.84 & 13.61 & 15.62 & 12.69 & 20.52 & 16.58 & 15.23 & 16.22 & 17.97 & 16.26 & 17.22 & 17.41 & 18.80 & 19.65 & 20.00 & 18.19 & 7.48 \\
\hline $\mathrm{ADF}$ & 3.96 & 3.41 & 3.61 & 3.64 & 3.59 & 4.12 & 3.50 & 5.29 & 4.31 & 3.93 & 16.03 & 4.91 & 4.68 & 4.77 & 4.51 & 5.05 & 5.25 & 5.77 & 4.99 & 8.44 \\
\hline Ash & 6.89 & 5.74 & 6.10 & 5.56 & 6.29 & 5.42 & 5.66 & 6.74 & 6.89 & 6.05 & 9.12 & 6.33 & 6.01 & 6.39 & 7.80 & 6.61 & 7.03 & 6.71 & 6.70 & 8.68 \\
\hline GE & 17.90 & 18.00 & 18.68 & 17.87 & 17.52 & 17.90 & 17.78 & 20.07 & 17.98 & 18.23 & 4.46 & 17.95 & 17.62 & 17.84 & 21.46 & 18.14 & 17.81 & 18.12 & 18.42 & 7.34 \\
\hline
\end{tabular}
ranged from 0.22 to $0.32 \%$ and averaged $0.27 \%$. Threonine

Table 3. Chemical composition of the control and the experimental diets for Exp. 1 (\% DM)

abcd Samples from different flour mills in a province.

${ }^{1} 15$ samples from 15 wheat flour mills in 10 provinces $(H E N=$ He'nan, HEB = Hebei, LN = Liaoning, SX = Shanxi, XJ = Xinjiang, JS = Jiangsu, GS = Gansu, SC = Sichuan, FJ = Fujian, HUB = Hubei).

${ }^{2} \mathrm{CV}=$ Coefficient of variation. 
Table 4. Energy concentration and apparent total digestibility of energy of the wheat shorts and red dog for Exp. $1^{1}$

\begin{tabular}{|c|c|c|c|c|c|c|c|c|c|c|c|c|c|c|c|c|c|c|c|c|c|}
\hline \multirow[b]{2}{*}{ Item } & \multicolumn{8}{|c|}{ Wheat red dog } & \multirow[b]{2}{*}{ Mean $^{2}$} & \multirow[b]{2}{*}{$\mathrm{CV}^{3}$} & \multicolumn{7}{|c|}{ Wheat shorts } & \multirow[b]{2}{*}{ Mean } & \multirow[b]{2}{*}{$\mathrm{CV}$} & \multicolumn{2}{|c|}{ p-value ${ }^{4}$} \\
\hline & HEN $^{\mathrm{a}}$ & $\mathrm{HEN}^{\mathrm{c}}$ & $\mathrm{HEB}^{\mathrm{a}}$ & $\mathrm{LN}$ & SX & $\mathrm{HEN}^{\mathrm{d}}$ & $\mathrm{XJ}$ & $\mathrm{JS}^{\mathrm{b}}$ & & & GS & $\mathrm{SC}$ & $\mathrm{HEN}^{\mathrm{b}}$ & HUB & FJ & $\mathrm{HEB}^{\mathrm{b}}$ & $\mathrm{JS}^{\mathrm{a}}$ & & & Overall & $\begin{array}{c}\text { WS } \\
\text { vs } \\
\text { RD }\end{array}$ \\
\hline $\begin{array}{l}\text { DE } \\
\text { (MJ/kg as-fed basis) }\end{array}$ & 13.67 & 14.52 & 13.96 & 13.21 & 13.17 & 13.36 & 12.06 & 13.08 & 13.38 & 5.38 & 12.22 & 12.05 & 11.96 & 11.56 & 12.59 & 11.75 & 11.67 & 11.97 & 2.97 & $<0.01$ & 0.02 \\
\hline $\begin{array}{l}\mathrm{ME} \\
\text { (MJ/kg as-fed basis) }\end{array}$ & 13.05 & 13.70 & 13.20 & 12.30 & 12.70 & 12.62 & 11.69 & 12.91 & 12.77 & 4.74 & 11.81 & 11.42 & 11.48 & 11.06 & 12.11 & 11.08 & 10.97 & 11.42 & 3.71 & $<0.01$ & 0.05 \\
\hline $\mathrm{DE}(\mathrm{MJ} / \mathrm{kg} \mathrm{DM})$ & 15.63 & 16.64 & 15.96 & 15.08 & 14.96 & 15.31 & 13.64 & 15.01 & 15.28 & 5.72 & 13.86 & 13.66 & 13.39 & 13.06 & 14.27 & 13.31 & 13.27 & 13.55 & 3.06 & $<0.01$ & 0.02 \\
\hline ME, MJ/kg DM & 14.92 & 15.71 & 15.08 & 14.04 & 14.43 & 14.47 & 13.22 & 14.82 & 14.59 & 5.10 & 13.40 & 12.93 & 12.86 & 12.49 & 13.73 & 12.56 & 12.48 & 12.92 & 3.74 & $<0.01$ & 0.48 \\
\hline ATTD of GE (\%) & 85.17 & 90.72 & 87.87 & 82.30 & 86.83 & 81.46 & 75.67 & 79.90 & 83.74 & 5.79 & 79.65 & 73.58 & 71.02 & 77.61 & 74.65 & 70.32 & 69.16 & 73.71 & 5.28 & $<0.01$ & 0.03 \\
\hline ME/DE (\%) & 95.48 & 94.36 & 94.51 & 93.13 & 96.43 & 94.50 & 96.88 & 98.72 & 95.50 & 1.86 & 96.68 & 94.71 & 95.99 & 95.66 & 96.21 & 94.36 & 94.03 & 95.38 & 1.06 & 0.14 & 0.16 \\
\hline
\end{tabular}

and tryptophan concentrations ranged from 0.34 to $0.49 \%$ and from 0.14 to $0.21 \%$ and averaged 0.53 and $0.18 \%$, respectively.

\section{Energy concentration and energy digestibility of wheat shorts and red dog}

Energy concentration and ATTD of GE of the wheat shorts and red dog are shown in Table 4. The DE (mean 13.80 MJ/kg) and ME (mean $13.20 \mathrm{MJ} / \mathrm{kg}$ ) of wheat shorts ranged from 13.06 to $15.01 \mathrm{MJ} / \mathrm{kg}$ and 12.48 to 14.82 $\mathrm{MJ} / \mathrm{kg}$ of DM, respectively. The DE and ME of red $\mathrm{dog}$ ranged from 13.31 to $15.96 \mathrm{MJ} / \mathrm{kg}$ and 12.56 to 15.08 $\mathrm{MJ} / \mathrm{kg}$ of DM, respectively. The difference among DE in wheat shorts was $1.95 \mathrm{MJ} / \mathrm{kg}$ and in red dog was 2.65 $\mathrm{MJ} / \mathrm{kg}$ of DM. The ratio of DE to ME calculated from 15 measured samples ranged from 93.13 to $98.72 \%$, with a mean value of $95.44 \%$.

\section{Prediction of energy values of wheat shorts and red dog}

$\mathrm{DE}$ and $\mathrm{ME}$ values can be predicted from the nutrients concentration of the chemical composition of wheat shorts and red dog. Some equations based on a single chemical characteristic showed a highly linear correlation. The NDF $(\mathrm{g} / \mathrm{kg}$ of $\mathrm{DM})$ was the best single predictor $\left(\mathrm{R}^{2}=0.84\right.$, $\mathrm{p}<0.01)$ in $\mathrm{DE}(\mathrm{MJ} / \mathrm{kg}$ of $\mathrm{DM})$ values of wheat shorts and red dog, followed by starch $\left(\mathrm{R}^{2}=0.77, \mathrm{p}<0.01\right), \mathrm{CF}\left(\mathrm{R}^{2}=\right.$ $0.75, \mathrm{p}<0.01)$, ash $\left(\mathrm{R}^{2}=0.75, \mathrm{p}<0.01\right)$, and total xylans $\left(\mathrm{R}^{2}\right.$ $=0.72, \mathrm{p}<0.01)$ concentrations. Multiple linear regression analyses were conducted to develop prediction equations for DE and ME values of wheat shorts and red dog based on the results of step-wise regression analysis (Table 5). The models were further improved by inclusion of ADF content in the DE model. The best model for prediction of DE was obtained: $\mathrm{DE}=-0.18 \times \mathrm{NDF}+0.20 \times \mathrm{ADF}+16.97\left(\mathrm{R}^{2}=0.87\right.$; $\mathrm{p}<0.01)$. In addition, more indicators were included in the ME equations, such as xylans, $\mathrm{CP}$ and $\mathrm{P}$. Moreover, DE and $\mathrm{ME}$ values were highly correlated $(\mathrm{ME}=0.92 \times \mathrm{DE}+0.44$; $\left.\mathrm{R}^{2}=0.96 ; \mathrm{p}<0.01\right)$.

Ileal digestibility of crude protein and amino acids (Exp. 2)

AID of nutrients values are shown in Table 9. Among the ten samples of wheat shorts and red dog, there was significant difference $(\mathrm{p}<0.01)$ in AID of DM, CP and most amino acids except for isoleucine, methionine,

Table 5. Prediction of energy value (MJ/kg of DM) from chemical composition (\% of DM) in wheat shorts and red dog

\begin{tabular}{rlrcr}
\hline No. & Regression equations & $\mathrm{R}^{2}$ & $\mathrm{p}$-value & $\mathrm{RSD}^{1}$ \\
\hline 1 & $\mathrm{DE}=-0.13 \times \mathrm{NDF}+16.92$ & 0.84 & $<0.01$ & 0.43 \\
2 & $\mathrm{DE}=0.60 \times \mathrm{Starch}+11.26$ & 0.77 & $<0.01$ & 0.52 \\
3 & $\mathrm{DE}=-4.60 \times \mathrm{CF}+16.51$ & 0.75 & $<0.01$ & 0.55 \\
4 & $\mathrm{DE}=-9.90 \times$ Ash+16.75 & $<0.01$ & 0.54 \\
5 & $\mathrm{DE}=-2.91 \times \mathrm{Xylan}+16.31$ & 0.75 & $<0.01$ & 0.58 \\
6 & $\mathrm{DE}=-0.18 \times \mathrm{NDF}+0.20 \times \mathrm{ADF}+16.97$ & 0.72 & $<0.01$ & 0.41 \\
7 & $\mathrm{ME}=-0.11 \times \mathrm{NDF}+16.01$ & 0.87 & $<0.01$ & 0.50 \\
8 & $\mathrm{ME}=-0.07 \times \mathrm{NDF}-0.12 \times \mathrm{Xylans}+15.98$ & 0.76 & $<0.01$ & 0.46 \\
9 & $\mathrm{ME}=-0.09 \times \mathrm{NDF}-0.16 \times \mathrm{Xylans}+0.20 \times \mathrm{CP}+13.28$ & 0.80 & $<0.01$ & 0.46 \\
10 & $\mathrm{ME}=-0.6 \times \mathrm{NDF}-0.16 \times \mathrm{Xylans}+0.26 \times \mathrm{CP}-2.02 \times \mathrm{P}+12.73$ & 0.85 & $<0.01$ & 0.37 \\
\hline
\end{tabular}

${ }^{1} \mathrm{RSD}=$ The root mean square of the error that applies to the whole model. 
Table 6. Chemical analysis of ten samples of wheat shorts and red dog used in Exp. 2 (\%, DM) ${ }^{1}$

\begin{tabular}{|c|c|c|c|c|c|c|c|c|c|c|c|c|c|c|}
\hline \multirow{2}{*}{ Item $(\%)$} & \multicolumn{5}{|c|}{ Wheat red dog } & \multirow{2}{*}{ Mean $^{2}$} & \multirow{2}{*}{$\mathrm{CV}^{3}$} & \multicolumn{5}{|c|}{ Wheat shorts } & \multirow{2}{*}{ Mean } & \multirow{2}{*}{$\mathrm{CV}$} \\
\hline & HLJ & HEB & LN & SX & XJ & & & GS & $\mathrm{SC}$ & HEN & SD & HUB & & \\
\hline$\overline{\mathrm{CP}}$ & 14.99 & 14.70 & 13.95 & 16.14 & 16.40 & 15.24 & 6.70 & 17.76 & 15.43 & 19.41 & 18.76 & 18.42 & 17.96 & 8.53 \\
\hline NDF & 8.54 & 9.37 & 11.11 & 16.66 & 20.79 & 13.29 & 39.50 & 29.62 & 21.21 & 25.58 & 25.07 & 26.68 & 25.63 & 11.84 \\
\hline $\mathrm{ADF}$ & 1.40 & 1.60 & 2.31 & 3.54 & 4.49 & 2.67 & 49.43 & 6.68 & 4.80 & 5.73 & 6.37 & 3.81 & 5.48 & 21.49 \\
\hline Crude fiber & 1.46 & 1.98 & 2.55 & 2.92 & 4.34 & 2.65 & 41.35 & 4.91 & 5.04 & 5.12 & 5.94 & 6.75 & 5.55 & 14.09 \\
\hline Calcium & 0.04 & 0.03 & 0.02 & 0.06 & 0.09 & 0.05 & 55.50 & 0.08 & 0.06 & 0.07 & 0.09 & 0.06 & 0.07 & 18.11 \\
\hline Phosphorus & 0.23 & 0.22 & 0.27 & 0.32 & 0.53 & 0.31 & 43.80 & 0.41 & 0.45 & 0.52 & 0.57 & 0.71 & 0.53 & 22.02 \\
\hline \multicolumn{15}{|c|}{ Indispensable amino acids } \\
\hline Arginine & 0.57 & 0.73 & 0.62 & 0.81 & 0.95 & 0.74 & 20.64 & 1.03 & 0.75 & 1.11 & 0.97 & 1.01 & 0.97 & 13.88 \\
\hline Histidine & 0.33 & 0.34 & 0.31 & 0.37 & 0.38 & 0.35 & 8.33 & 0.43 & 0.36 & 0.44 & 0.43 & 0.44 & 0.42 & 8.07 \\
\hline Isoleucine & 0.45 & 0.47 & 0.43 & 0.50 & 0.49 & 0.47 & 6.12 & 0.50 & 0.49 & 0.56 & 0.55 & 0.56 & 0.53 & 6.43 \\
\hline Leucine & 0.99 & 0.99 & 0.91 & 1.06 & 1.02 & 0.99 & 5.54 & 1.09 & 1.03 & 1.17 & 1.14 & 1.19 & 1.12 & 5.75 \\
\hline Lysine & 0.36 & 0.47 & 0.41 & 0.54 & 0.62 & 0.48 & 21.50 & 0.67 & 0.53 & 0.75 & 0.61 & 0.60 & 0.63 & 13.07 \\
\hline Methionine & 0.22 & 0.25 & 0.24 & 0.28 & 0.27 & 0.25 & 9.47 & 0.28 & 0.27 & 0.32 & 0.29 & 0.29 & 0.29 & 6.45 \\
\hline Phenylalanine & 0.67 & 0.65 & 0.63 & 0.66 & 0.66 & 0.65 & 2.32 & 0.65 & 0.70 & 0.78 & 0.78 & 0.73 & 0.73 & 7.61 \\
\hline Threonine & 0.39 & 0.43 & 0.39 & 0.49 & 0.50 & 0.44 & 12.03 & 0.54 & 0.49 & 0.60 & 0.54 & 0.55 & 0.54 & 7.19 \\
\hline Tryptophan & 0.18 & 0.17 & 0.16 & 0.21 & 0.20 & 0.18 & 11.27 & 0.24 & 0.20 & 0.26 & 0.17 & 0.21 & 0.22 & 16.24 \\
\hline Valine & 0.62 & 0.65 & 0.58 & 0.68 & 0.74 & 0.65 & 9.28 & 0.74 & 0.73 & 0.90 & 0.78 & 0.77 & 0.78 & 8.68 \\
\hline Lys/ $/ \mathrm{CP}^{3}$ & 2.92 & 3.20 & 3.80 & 2.36 & 3.36 & 3.13 & 17.04 & 3.44 & 3.30 & 3.24 & 3.86 & 3.77 & 3.52 & 7.91 \\
\hline
\end{tabular}

${ }^{1}$ Wheat shorts and red dog samples were collected in 10 provinces (HLJ = Heilongjiang, HEB = Hebei, LN = Liaoning, SX = Shanxi, XJ = Xinjiang, GS $=$ Gansu, $\mathrm{SC}=$ Sichuan, HEN = He'nan, $\mathrm{SD}=$ Shandong, $\mathrm{HUB}=$ Hubei $)$.

${ }^{2}$ Mean: 5 observations. ${ }^{3} \mathrm{CV}=$ Coefficient of variation.

${ }^{4} \mathrm{LYS} / \mathrm{CP}=$ Lysine concentration per unit of crude protein (g/100 g of crude protein).

phenylalanine, and tryptophan. The AID of DM ranged from 76.15 to $87.06 \%$, with a mean value of $80.91 \%$.

The AID of CP in wheat shorts ranged from $76.58 \%$ (sample SC) to $80.33 \%$ (sample GS), with a mean value of $78.80 \%$. Otherwise, the values of red dog ranged from

Table 7. Ingredient of composition of experimental diets in Exp. 2 $(\%$, as-fed $)$

\begin{tabular}{|c|c|c|}
\hline Ingredient (\%) & $\begin{array}{l}\text { Wheat shorts or } \\
\text { red dog diet }\end{array}$ & Nitrogen-free diet \\
\hline Wheat shorts or red dog & 60.00 & - \\
\hline Corn starch & 24.30 & 73.35 \\
\hline Sucrose & 10.00 & 15.00 \\
\hline Cellulose acetate $^{1}$ & - & 4.00 \\
\hline Soybean oil & 2.00 & 3.00 \\
\hline Limestone & 0.60 & - \\
\hline Dicalcium phosphate & 2.00 & 3.00 \\
\hline Sodium chloride & 0.30 & 0.45 \\
\hline Chromic oxide & 0.30 & 0.30 \\
\hline Potassium carbonate & - & 0.30 \\
\hline Magnesium oxide & - & 0.10 \\
\hline Vitamin-mineral premix ${ }^{2}$ & 0.50 & 0.50 \\
\hline \multicolumn{3}{|c|}{$\begin{array}{l}{ }^{1} \text { Made by Chemical Reagents Company, Beijing, China. } \\
{ }^{2} \text { Provided the following per kilogram of diet: } \mathrm{Mn}, 50 \mathrm{mg} \text { as } \mathrm{MnO} ; \mathrm{Fe} \text {, } \\
125 \mathrm{mg} \text { as } \mathrm{FeSO}_{4} \cdot \mathrm{H}_{2} \mathrm{O} ; \mathrm{Zn}, 125 \mathrm{mg} \text { as } \mathrm{ZnO} ; \mathrm{Cu}, 150 \mathrm{mg} \text { as } \mathrm{CuSO}_{4} \cdot 5 \mathrm{H}_{2} \mathrm{O} \text {; } \\
\mathrm{I}, 50 \mathrm{mg} \text { as } \mathrm{CaI}_{2} ; \mathrm{Se}, 0.48 \mathrm{mg} \text { as } \mathrm{Na}_{2} \mathrm{SeO}_{3} \text {, retinyl acetate, } 4,500 \mathrm{IU} \text {; } \\
\text { cholecalciferol, } 1,350 \mathrm{IU} \text {; DL- } \alpha \text {-tocopheryl acetate, } 13.5 \mathrm{mg} \text {; menadione } \\
\text { sodium bisulfite complex, } 2.7 \mathrm{mg} \text {; niacin, } 18 \mathrm{mg} \text {; vitamin } \mathrm{B}_{12}, 27.6 \mu \mathrm{g} \text {; } \\
\text { thiamine, } 0.6 \mathrm{mg} \text {; pyridoxine, } 0.9 \mathrm{mg} \text {; riboflavin, } 1.8 \mathrm{mg} \text {; D-ca- } \\
\text { pantothenate, } 10.8 \mathrm{mg} \text {; nicotinic acid, } 30.3 \mathrm{mg} \text {; choline chloride, } 210 \mathrm{mg} \text {. }\end{array}$} \\
\hline
\end{tabular}

74.83 (sample HLJ) to $77.53 \%$ (sample LN) and averaged $76.50 \%$. The AID of lysine ranged from 76.31 to $86.28 \%$ in wheat shorts and 65.66 to $83.52 \%$ in red dog. In wheat shorts and red dog, the AID of methionine (85.84 to $90.53 \%)$ and tryptophan (77.42 to $81.49 \%)$ showed less variation than threonine (65.50 to $78.07 \%$ ). The SID values of CP and amino acids presented (Table 10) were high among samples. The methionine (mean 92.88\%) for SID was higher than tryptophan (mean $89.32 \%$ ), threonine (mean $87.89 \%$ ) and lysine (mean $87.78 \%$ ).

\section{Prediction of nitrogen and amino acids digestibility in wheat shorts and red dog}

Regression equations (Table 11) among N, the AID and SID for amino acids with chemical characteristics (\% of DM) of wheat shorts and red dog indicated that variable $\mathrm{N}$, amino acids and fiber content in samples mainly predicted the digestibility.

The equations obtained followed a stepwise regression procedure showing that $\mathrm{N}$ digestibility could be evaluated from CP values. In addition, the best predictor for AID of lysine was the concentration of lysine in CP (Table 11) according to a linear stepwise regression $\left(\mathrm{R}^{2}=0.83\right.$, $\mathrm{p}<0.01)$. However, the SID of lysine had a relatively poor relationship with the lysine concentration in $\mathrm{CP}\left(\mathrm{R}^{2}=0.65\right.$, $\mathrm{p}<0.01)$. Moreover, the SID of threonine and methionine showed poorer models than SID of lysine. 
Table 8. Analyzed composition of experimental diets used in Exp. 2 (\% DM)

\begin{tabular}{|c|c|c|c|c|c|c|c|c|c|c|c|c|c|c|}
\hline \multirow{2}{*}{ Item $(\%)$} & \multicolumn{5}{|c|}{ Wheat red dog diets } & \multirow{2}{*}{ Mean } & \multirow{2}{*}{$\mathrm{CV}^{2}$} & \multicolumn{5}{|c|}{ Wheat shorts diets } & \multirow{2}{*}{ Mean } & \multirow{2}{*}{$\mathrm{CV}$} \\
\hline & HLJ & HEB & $\mathrm{LN}$ & SX & XJ & & & GS & $\mathrm{SC}$ & HEN & SD & HUB & & \\
\hline$\overline{\mathrm{CP}}$ & 8.70 & 8.74 & 8.21 & 9.39 & 9.79 & 8.97 & 6.95 & 9.97 & 9.92 & 11.01 & 11.03 & 10.73 & 10.53 & 5.21 \\
\hline NDF & 6.30 & 7.72 & 16.64 & 13.70 & 16.04 & 12.08 & 39.60 & 17.79 & 15.66 & 15.40 & 16.25 & 19.73 & 16.97 & 10.62 \\
\hline $\mathrm{ADF}$ & 1.35 & 1.27 & 2.17 & 2.42 & 3.17 & 2.08 & 38.09 & 2.31 & 3.80 & 4.24 & 3.64 & 4.91 & 3.78 & 25.34 \\
\hline \multicolumn{15}{|c|}{ Indispensable amino acids } \\
\hline Arginine & 0.52 & 0.42 & 0.38 & 0.61 & 0.58 & 0.50 & 19.84 & 0.62 & 0.65 & 0.46 & 0.35 & 0.60 & 0.54 & 23.69 \\
\hline Histidine & 0.23 & 0.20 & 0.20 & 0.27 & 0.25 & 0.23 & 13.40 & 0.26 & 0.28 & 0.21 & 0.18 & 0.26 & 0.24 & 17.43 \\
\hline Isoleucine & 0.31 & 0.29 & 0.26 & 0.31 & 0.28 & 0.29 & 7.31 & 0.31 & 0.32 & 0.29 & 0.26 & 0.32 & 0.30 & 8.50 \\
\hline Leucine & 0.69 & 0.61 & 0.55 & 0.69 & 0.61 & 0.63 & 9.52 & 0.69 & 0.71 & 0.64 & 0.59 & 0.72 & 0.67 & 8.11 \\
\hline Lysine & 0.34 & 0.26 & 0.25 & 0.34 & 0.37 & 0.31 & 17.17 & 0.42 & 0.42 & 0.30 & 0.20 & 0.37 & 0.34 & 27.30 \\
\hline Methionine & 0.17 & 0.15 & 0.13 & 0.17 & 0.17 & 0.16 & 11.32 & 0.17 & 0.18 & 0.16 & 0.14 & 0.19 & 0.17 & 11.45 \\
\hline Phenylalanine & 0.42 & 0.37 & 0.31 & 0.44 & 0.37 & 0.38 & 13.27 & 0.41 & 0.43 & 0.43 & 0.38 & 0.45 & 0.42 & 6.30 \\
\hline Threonine & 0.31 & 0.26 & 0.25 & 0.33 & 0.30 & 0.29 & 11.69 & 0.34 & 0.36 & 0.29 & 0.24 & 0.33 & 0.31 & 15.27 \\
\hline Tryptophan & 0.11 & 0.10 & 0.08 & 0.12 & 0.11 & 0.10 & 14.58 & 0.12 & 0.13 & 0.12 & 0.09 & 0.14 & 0.12 & 15.59 \\
\hline Valine & 0.45 & 0.36 & 0.36 & 0.47 & 0.40 & 0.41 & 12.43 & 0.49 & 0.47 & 0.40 & 0.34 & 0.45 & 0.43 & 14.05 \\
\hline
\end{tabular}

${ }^{1}$ Wheat shorts and red dog samples were collected in 10 provinces (HLJ = Heilongjiang, HEB = Hebei, LN = Liaoning, SX = Shanxi, XJ = Xinjiang, GS $=$ Gansu, $\mathrm{SC}=$ Sichuan, HEN $=$ He'nan, $\mathrm{SD}=$ Shandong, HUB $=$ Hubei $)$ Values are means for 6 observations.

${ }^{2} \mathrm{CV}=$ Coefficient of variation.

\section{DISCUSSION}

Definitions and classifications of wheat milling byproducts vary widely among the NRC (1998), Chinese Feed Database (2005) and Sauvant et al. (2004). The values of CP, $\mathrm{NDF}$ and ADF in wheat shorts and red dog (NRC, 1998) were within the range obtained in our study, but mean values of $\mathrm{Ca}, \mathrm{P}, \mathrm{EE}$ for the samples obtained in the current study were slightly lower than NRC (1998) values. The amino acids values in wheat shorts and red dog were also slightly lower than previously reported data (NRC, 1988), with the exception of methionine, tryptophan and valine. It could be concluded that the wheat shorts and red dog obtained have more fiber in aleurone and pericarp leading to the higher amino acids content (Cromwell et al., 2000; Sauvant et al., 2004; Chinese Feed Database, 2005). Similarly the relationship of NDF with lysine content in fourteen sources of wheat middlings were also positively correlated with Cromwell's (2000) study $\left(\mathrm{R}^{2}=0.72\right)$. Cromwell et al. (2000) showed a similar relationship of CP concentration with amino acids concentrations in wheat middlings. In all, wheat pericarp and aleurone, as well as wheat functional proteins (albumins and globulins), have higher amino acids concentrations than endosperm except

Table 9. Apparent ileal digestibility (\%) of dry matter, crude protein and amino acids in wheat shorts and red dog tested in Exp. $2(\%$ as fed)

\begin{tabular}{|c|c|c|c|c|c|c|c|c|c|c|c|c|c|c|c|c|}
\hline \multirow[b]{2}{*}{ Item $(\%)$} & \multicolumn{5}{|c|}{ Wheat red dog } & \multirow[b]{2}{*}{ Mean } & \multirow[b]{2}{*}{$\mathrm{CV}^{2}$} & \multicolumn{5}{|c|}{ Wheat shorts } & \multirow[b]{2}{*}{ Mean } & \multirow[b]{2}{*}{$\mathrm{CV}$} & \multicolumn{2}{|c|}{ p-value ${ }^{3}$} \\
\hline & HLJ & HEB & $\mathrm{LN}$ & SX & $\mathrm{XJ}$ & & & GS & $\mathrm{SC}$ & HEN & SD & HUB & & & Overall & $\begin{array}{c}\text { WS vs } \\
\text { RD }\end{array}$ \\
\hline Crude protein & 74.83 & 77.45 & 77.53 & 75.93 & 76.78 & 76.50 & 1.48 & 80.15 & 76.58 & 79.43 & 80.33 & 77.58 & 78.81 & 2.10 & $<0.01$ & 0.32 \\
\hline Dry matter & 81.09 & 87.06 & 83.59 & 76.23 & 78.92 & 81.38 & 5.13 & 78.87 & 78.69 & 83.29 & 85.26 & 76.15 & 80.45 & 4.62 & $<0.01$ & 0.81 \\
\hline \multicolumn{17}{|c|}{ Indispensable amino acids } \\
\hline Arginine & 82.08 & 88.90 & 87.90 & 85.46 & 89.73 & 86.81 & 3.56 & 91.98 & 86.48 & 88.35 & 91.20 & 88.53 & 89.31 & 2.52 & $<0.01$ & $<0.01$ \\
\hline Histidine & 81.81 & 87.59 & 85.92 & 84.20 & 84.64 & 84.83 & 2.53 & 87.22 & 83.63 & 87.06 & 87.05 & 83.99 & 85.79 & 2.11 & $<0.01$ & $<0.01$ \\
\hline Isoleucine & 80.79 & 86.30 & 82.91 & 83.74 & 83.85 & 83.52 & 2.37 & 86.87 & 83.58 & 85.82 & 84.49 & 82.53 & 84.66 & 2.04 & 0.02 & 0.05 \\
\hline Leucine & 85.04 & 88.41 & 85.77 & 86.00 & 85.64 & 86.17 & 1.51 & 88.57 & 85.35 & 87.81 & 86.50 & 84.92 & 86.63 & 1.80 & 0.01 & 0.04 \\
\hline Lysine & 65.66 & 78.69 & 75.11 & 75.92 & 83.52 & 75.78 & 8.63 & 86.28 & 76.31 & 81.86 & 80.27 & 76.88 & 80.32 & 5.05 & $<0.01$ & 0.02 \\
\hline Methionine & 89.82 & 88.86 & 87.37 & 88.28 & 89.27 & 88.72 & 1.06 & 90.53 & 85.87 & 85.84 & 87.35 & 87.07 & 87.33 & 2.19 & 0.02 & 0.23 \\
\hline Phenylalanine & 87.87 & 89.23 & 86.49 & 88.30 & 86.38 & 87.65 & 1.39 & 89.04 & 85.98 & 88.49 & 87.69 & 86.90 & 87.62 & 1.40 & 0.02 & 0.09 \\
\hline Threonine & 65.50 & 74.34 & 68.19 & 70.61 & 71.37 & 70.00 & 4.77 & 78.07 & 71.46 & 77.86 & 74.98 & 71.48 & 74.77 & 4.35 & $<0.01$ & 0.03 \\
\hline Tryptophan & 80.60 & 81.04 & 78.83 & 81.49 & 80.75 & 80.54 & 1.26 & 79.60 & 77.42 & 79.18 & 81.74 & 78.00 & 79.19 & 2.11 & 0.02 & 0.44 \\
\hline Valine & 77.70 & 84.02 & 81.38 & 81.02 & 82.88 & 81.40 & 2.94 & 87.36 & 81.67 & 84.19 & 84.05 & 82.20 & 83.89 & 2.66 & $<0.01$ & 0.02 \\
\hline
\end{tabular}

${ }^{1}$ Wheat shorts and red dog samples were collected in 10 provinces (HLJ = Heilongjiang, HEB = Hebei, LN = Liaoning, SX = Shanxi, XJ = Xinjiang, GS $=$ Gansu, $\mathrm{SC}=$ Sichuan, HEN = He'nan, $\mathrm{SD}=$ Shandong, HUB = Hubei). Values are means for 6 observations.

${ }^{2} \mathrm{CV}=$ Coefficient of variation.

${ }^{3}$ p-value: Overall $=$ Comparisons among 10 wheat shorts and red dog. WS vs RD $=$ Comparison of the wheat shorts and red dog ingredients. 
Table 10. Standardized ileal digestibility $(\%)$ of crude protein and amino acids in wheat shorts and red dog tested in Exp. $2(\% \text { as fed })^{1}$

\begin{tabular}{|c|c|c|c|c|c|c|c|c|c|c|c|c|c|c|c|c|}
\hline \multirow[b]{2}{*}{ Item $(\%)$} & \multicolumn{5}{|c|}{ Wheat red dog } & \multirow[b]{2}{*}{ Mean } & \multirow[b]{2}{*}{$\mathrm{CV}^{2}$} & \multicolumn{5}{|c|}{ Wheat shorts } & \multirow[b]{2}{*}{ Mean } & \multirow[b]{2}{*}{$\mathrm{CV}$} & \multicolumn{2}{|c|}{ p-value ${ }^{3}$} \\
\hline & HLJ & HEB & $\mathrm{LN}$ & SX & XJ & & & GS & $\mathrm{SC}$ & HEN & SD & HUB & & & Overall & $\begin{array}{c}\text { WS vs } \\
\text { RD }\end{array}$ \\
\hline Crude prote & 89.25 & 1.20 & 89.31 & 90.02 & 92.84 & 90.52 & 1.67 & 90.94 & 90.47 & 93.97 & 93.42 & 90.37 & 91.83 & 1.88 & $<0.01$ & 0.62 \\
\hline \multicolumn{17}{|c|}{ Indispensable amino acids } \\
\hline Arginine & 90.32 & 92.58 & 96.78 & & 94.70 & 93.21 & 2.74 & 95.96 & 92.06 & 92.86 & 95.92 & 96.49 & 94.66 & 2.15 & $<0.01$ & 0.39 \\
\hline & .57 & 92.04 & 95.04 & 93.27 & 92.62 & 92.71 & & 95.34 & 91.99 & 92.94 & 93.39 & 95.83 & 93.90 & 1.74 & $<0.01$ & 0.75 \\
\hline Isolet & 87.61 & 90.49 & 92.71 & 91.97 & 92.32 & 91.02 & 2.29 & 93.78 & 91.08 & 91.26 & 92.07 & 94.26 & 92.49 & 1.57 & $<0.01$ & 0.48 \\
\hline & 91.51 & 92.29 & 94.99 & 93.71 & 93.56 & 93.21 & 1.45 & 94.75 & 92.48 & 93.24 & 93.63 & 94.88 & 93.80 & 1.09 & $<0.01$ & 0.53 \\
\hline & .54 & 86.63 & 88.72 & & 91.39 & 86.32 & & 94.41 & 84.81 & 88.30 & 88.29 & 90.36 & 89.23 & 3.94 & 0.02 & 0.69 \\
\hline Methion & 95.26 & 92.12 & 93.53 & 92.98 & 93.95 & 93.57 & 1.25 & 94.49 & 90.43 & 89.35 & 91.98 & 94.66 & 92.18 & 2.58 & 0.01 & 0.12 \\
\hline Phenyl & 93.03 & 92.94 & 95.00 & 94.35 & 92.12 & 93.49 & 1.24 & 95.62 & 92.03 & 93.34 & 93.90 & 96.07 & 94.19 & 1.76 & $<0.01$ & 0.60 \\
\hline & & 86.63 & 89.06 & 87.41 & 84.78 & 86.05 & 2.98 & 91.10 & 87.09 & 90.03 & 89.36 & 91.09 & 89.73 & 1.84 & 0.02 & 0.68 \\
\hline & 88.89 & 87.22 & 90.84 & 90.18 & 91.06 & 89.64 & 1.78 & 89.13 & 85.24 & 85.19 & 90.48 & 94.95 & 89.00 & 4.57 & 0.02 & 0.80 \\
\hline Valine & 87.48 & 90.17 & 91.84 & 89.28 & 91.14 & 89.98 & 1.89 & 94.96 & 89.27 & 90.03 & 91.97 & 95.13 & 92.27 & 2.94 & $<0.01$ & 0.21 \\
\hline
\end{tabular}

${ }^{1}$ Wheat shorts and red dog samples were collected in 10 provinces (HLJ = Heilongiiang, HEB = Hebei, LN = Liaoning, SX = Shanxi, XJ = Xinjiang, GS $=$ Gansu, $\mathrm{SC}=$ Sichuan, HEN $=$ He'nan, $\mathrm{SD}=$ Shandong, $\mathrm{HUB}=$ Hubei $)$. Values are means for 6 observations .

${ }^{2} \mathrm{CV}=$ Coefficient of variation.

${ }^{3}$ p-value: Overall $=$ Comparisons among 10 wheat shorts and red dog. WS vs RD $=$ Comparison of the wheat shorts and red dog ingredients.

for phenylalanine (Jondreville et al., 2000). Besides tryptophan, other amino acids' contents were highly correlated with CP in wheat shorts and red dog samples $\left(\mathrm{R}^{2}>0.80\right.$, Data are not shown).

Wheat shorts and red dog in the NRC (1998) of DE values were 14.19 and $14.93 \mathrm{MJ} / \mathrm{kg}$ of $\mathrm{DM}$ and $\mathrm{ME}$ values were 13.40 and $13.90 \mathrm{MJ} / \mathrm{kg}$ of $\mathrm{DM}$, respectively. The average DE for the wheat shorts and red dog determined in the present study were 13.79 and $15.06 \mathrm{MJ} / \mathrm{kg}$ of DM, and ME averaged 13.24 and $14.30 \mathrm{MJ} / \mathrm{kg}$ of DM, respectively. Therefore, the values of DE and ME obtained in the current study agreed with the data published by NRC (1998). Likewise, Patience et al. (1977) reported that several

Table 11. Prediction of amino acid digestibility (\% as fed) from chemical composition (\% of DM) in wheat shorts and red dog

\begin{tabular}{llccc}
\hline No. & Regression equations $^{1}$ & $\mathrm{R}^{2}$ & p-value & RSD $^{2}$ \\
\hline 1 & AID N $=0.67 \times \mathrm{CP}+66.54$ & 0.47 & $<0.05$ & 1.25 \\
2 & AID LYS $=11.4 \times \mathrm{LYS} / \mathrm{CP}+40.13$ & 0.83 & $<0.01$ & 2.23 \\
3 & AID THR $=1.59 \times \mathrm{CP}+49.14$ & 0.63 & $<0.01$ & 2.76 \\
4 & AID MET $=-0.41 \times \mathrm{CF}+89.69$ & 0.20 & $\mathrm{NS}^{3}$ & 1.35 \\
5 & SID N $=0.73 \times \mathrm{CP}+79.01$ & 0.64 & $<0.01$ & 0.96 \\
6 & SID LYS $=6.41 \times \mathrm{LYS} / \mathrm{CP}+66.46$ & 0.51 & $<0.01$ & 2.71 \\
7 & SID THR $=0.99 \times \mathrm{CP}+73.45$ & 0.37 & $<0.05$ & 2.12 \\
8 & SID MET $=-0.69 \times \mathrm{CF}+95.11$ & 0.41 & 0.05 & 1.41 \\
\hline
\end{tabular}

${ }^{1}$ AID N = Apparent ileal digestibility of nitrogen, AID LYS = Apparent ileal digestibility of lysine, AID THR = Apparent ileal digestibility of threonine, AID MET = Apparent ileal digestibility of methionine, SID N $=$ Standardized ileal digestibility of nitrogen, SID LYS $=$ Standardized ileal digestibility of lysine, LYS/CP = Lysine concentration per unit of crude protein $(\mathrm{g} / 100 \mathrm{~g}$ of crude protein), SID MET $=$ Standardized ileal digestibility of methionine, SID THR $=$ Standardized ileal digestibility of threonine.

${ }^{2} \mathrm{RSD}=$ The root mean square of the error that applies to the whole model.

${ }^{3} \mathrm{NS}=$ Not significant. samples of wheat shorts had a value from 12.13 to 14.39 $\mathrm{MJ} / \mathrm{kg}$ DE of DM. Batterham et al. (1980) reported that DE values of eight wheat by-products (mainly wheat middlings) contained from 10.90 to $14.10 \mathrm{MJ} / \mathrm{kg}$ of DM. Wheat milling by-products like wheat shorts and middlings generally had a higher fiber content compared to the parent grains, were therefore not as well digested by growing pigs, and have a lower energy density (Holden and Zimmerman, 1991). From the published nutritional values of wheat milling byproducts, it does not make much sense to compare the nutritional values of wheat milling by-products statically due to the large variability of compositions therefore dynamic comparisons and prediction models are more necessary and meaningful.

Few reporters previously published the amino acids digestibility of the wheat shorts and red dog, specifically regarding SID values. There were no differences between wheat shorts and red dog in amino acids for SID values in the study. This may be explained that in the study the NDF content in the diets had a mean value of $14.57 \%$ and can tolerate up to $16.80 \%$ NDF without a depression in ileal amino acids digestibility as reported by $\mathrm{Li}$ et al. (1994). That is to say the CP and amino acids content in the wheat shorts and red dog may play a more important role in amino acids digestibility.

The AID of amino acids in wheat shorts were generally higher than previously reported wheat shorts values (NRC, 1998; Huang et al., 1999), but similar to the values of the Chinese Feed Database (2005). Most amino acids for SID were rather high caused by higher endogenous losses excreted by small intestines. The endogenous losses caused by amino acids digested in the small intestine depended on the sequencing of enzymatic hydrolysis to each amino acid (Low, 1980) and fibers or anti-nutritional factors were fed 
(Stein et al., 2007). In addition, the values of AID and SID of amino acids in the study were within the range of wheat shorts and wheat feed flour values (Sauvant et al., 2004). Among the ten samples of wheat shorts and red dog, differences $(\mathrm{p}<0.05)$ in the SID for $\mathrm{CP}$ and amino acids were observed. The SID were higher than AID values because wheat shorts and red dog diets containing relatively lower CP and amino acids concentrations usually had lower AID due to endogenous losses contributing relatively more to the ileal output of amino acids (Fan et al., 1994). Also, the low ileal digestibility of lysine compared to other amino acids probably results lysine being highly concentrated in the fibrous part of the wheat grains, as well as in the great decrease in digestibility in wheat shorts and red dog (Jondreville et al., 2000).

Considerable variation exists in the DE values in wheat milling by-products (Batterham et al., 1980) and if energy values were not accurately predicted, it would result in great differences between actual and expected diet DE and ME content. However, limited published information was available on the complete chemical composition correlated with the DE and ME of wheat shorts and red dog. Correlation coefficients and prediction equations with chemical compositions clearly indicated that fibrous components predominantly determined the energy values. In the ME stepwise regression equations, NDF, xylans, CP, and $\mathrm{P}$ came into the model successively. As expected, the higher dietary fiber content, the lower the digestibility of energy values. Several researchers have been able to accurately estimate the energy level in wheat milling byproducts (Batterham et al., 1980; Wan et al., 2009) with NDF as the primary predictor variable. NDF, a total measurement of cellulose, hemi-cellulose and lignin, was the most significant factor affecting the DE and $\mathrm{ME}$ variation. Simple regression increased $1 \%$ in NDF, leading to a $0.74 \%(0.13 \mathrm{MJ})$ decrease in DE (Eq. 1) and a decrease of $0.66 \%(0.11 \mathrm{MJ})$ (Eq. 7) in ME values in wheat shorts and red dog (Table 5). In addition, Batterham's (1980) equation predicting $\mathrm{DE}$ values of wheat by-products showed a similar result with a $1 \%$ increase in NDF leading to $0.66 \%$ decrease in DE values, slightly lower than the equation in this study. Compared with the data of correlation coefficients (Data are not shown) among DE of DM values of samples and NDF, ADF, ash, EE and GE were $-0.92,-0.76,-0.86,-0.57$ and 0.02 in the study, respectively. Interestingly, the coefficient of $\mathrm{EE}$ was negative with energy values in the study and similar results were found in other cereal grain feedstuff (unpublished data) in our lab. Sorghum showed the same result in Batterham's study, and the reason for this was likely due to the negative relationship $\left(R^{2}=0.54, \mathrm{p}<0.01\right)$ between starch and EE contents of the wheat shorts and red dog diets. This inverse relationship should result in the maintenance of a relatively high content of available energy in wheat shorts and red dog in despite of lower EE content, which may be explained that the energy contribution of EE in cereal grains are low and digestibility were lower than extracted EE and thus could nearly be ignored. Total xylans concentration was negatively correlated with DE content, which was a specific component of none starch polysaccharides and a more accurate measure of individual monomeric sugars (Kim et al., 2005). It has been reported that xylans are strongly correlated with energy values of wheat and byproducts in many reports. The $\mathrm{R}^{2}$ reached 0.71 using xylans as a single indicator to predict the DE values, which was not superior to NDF as a predictor in the study. However, Zijlstra et al. (1999) reported the total xylans were superior for prediction of DE content of wheat over NDF in growing pigs. The contradictions might partly be explained by different producing areas and different wheat sources of wheat shorts and red dog in the study, and NDF containing minimal pectin content in by-products not in whole wheat might provide similar or better accuracy than the use of xylans that showed less variation in samples than NDF for prediction of DE content (Kim et al., 2005). From these equations, the result showed that crude fiber content was strongly correlated with ash, xylans, starch and detergent fiber in which these predictors showed a rather high $\mathrm{R}$ square and no indicators came into prediction models to increase the accuracy, therefore, no more multiple regression equations were founded.

When predicting $\mathrm{N}$ and amino acids digestibility with stepwise regression in SAS, only one variable entered to into the models in each of the equations. As previously reported by Jondreville et al. (2000), except for the indicator of the ratio of dietary fiber to the amino acid content, the nitrogen bound to NDF residue were also thought as relevant predictors for amino acid in true ileal digestibility of wheat milling by-products. The prediction equations proposed were more accurate and meaningful as they may represent the probable increase of both endogenous losses and the amount of undigested protein from wheat by-products. The accuracy of SID models were all poor than the AID as a single predictor such as fiber and amino acids after correcting the endogenous nitrogen and amino acids losses. As to lysine digestibility, the lysine concentration per unit of $\mathrm{CP}$ appeared as a quick and reliable indicator for prediction of lysine digestibility (Cozannet et al., 2010). The results of current experiment indicate that lysine concentration per unit of $\mathrm{CP}$ was positively correlated with AID and SID for lysine. However, dietary fiber concentrations relative to amino acid concentrations can not show a good predictive result in this study. For example, compared to lysine content in samples, 
because of its constant and low concentrations of methionine and tryptophan, the digestibility of these two amino acids did not have good relationships with some predictors, seeming to be influenced more by the combined actions of chemical composition.

\section{CONCLUSION}

In summary, DE and $\mathrm{ME}$ values among fifteen wheat shorts and red dog samples are widely ranged and are highly correlated with the cell wall carbohydrates. As to amino acids digestibility, wheat shorts and red dog varies among various sources, and lysine digestibilities have more variation than other amino acids and are more predictable. Further research is warranted to confirm the results of the current experiment and estimate more accurate prediction equations based on more systematic chemical composition.

\section{ACKNOWLEDGEMENT}

This research was financially supported by the Special Public Sector Fund in Agriculture (200903006).

\section{REFERENCES}

AAFCO. 1996. Official publication. Assoc. Am. Feed Control Off. Inc., St. Louis. MO, USA.

AOAC. 2000. Official methods of analysis. 17th ed. Association of Official Analytical Chemists, Arlington, VA, USA.

Adeola, O. 2001. Digestion and balance techniques in pigs. In: Swine Nutrition, 2nd ed. (Ed. D. J. Lewis and L. L. Southern). CRC Press, New York, pp. 903-916.

Batterham, E. S., C. E. Lewis, R. F. Lowe and C. J. McMillan. 1980. Digestible energy content of cereals and wheat byproducts for growing-pigs. Anim. Prod. 31:259-271.

Blasi, D. A., G. L. Kuhl, J. S. Drouillard, C. R. Reed, D. M. TrigoStockli, K. C. Behnke and F. J. Fairchild. 1998. Wheat middlings: Composition, feeding value, and storage guidelines. MF-2353. Kansas State University. Agricultural Experiment Station and Cooperative Extension Service, Manhattan, Kansas.

Chinese Feed Database. 2005. Tables of feed composition and nutritive values for pigs in China. The Center of Chinese Feed Database Information, Beijing. http://www.chinafeeddata. org.cn Accessed May 2007 (in Chinese).

Cozannet, P., Y. Primot, C. Gady, J. P. Metayer, P. Callu, M. Lessire, F. Skiba and J. Noblet. 2010. Ileal digestibility of amino acids in wheat distillers dried grains with solubles for pigs. Anim. Feed Sci. Technol. 158:177-186.

Cromwell, G. L., T. R. Cline, J. D. Crenshaw, T. D. Crenshaw, R. A. Easter, R. C. Ewan, C. R. Hamilton, G. M. Hill, A. J. Lewis, D. C. Mahan, J. L. Nelssen, J. E. Pettigrew, T. L. Veum and J. T. Yen. 2000. Variability among sources and laboratories in analyses of wheat middlings. J. Anim. Sci. 78:2652-2658.

Eklund, M., R. Mosenthin, H. -P. Piepho and M. R. Rademacher. 2008. Estimates of basal ileal endogenous losses of aminoa acids by regression analysis and determination of standardized ileal aminoa acid digestibilities from casein in newly weaned pigs. J. Sci. Food Agric. 88:641-651.

Erickson, J. P., E. R. Miller, P. K. Ku, G. F. Collings and J. R. Black. 1985. Wheat middlings as a source of energy, aminoacids, phosphorus and pellet binding quality for swine diets. J. Anim. Sci. 60:1012-1020.

Fan, M. Z., W. C. Sauer and K. A. Lien. 1994. Effect of dietary amino acid level on the determination of apparent ileal amino acid digestibility in pigs. J. Anim. Sci. 72:2851-2859.

Fan, M. Z. and W. C. Sauer. 1995a. Determination of apparent ileal amino acid digestibility in barley and canola meal for pigs with direct difference, regression methods. J. Anim. Sci. 73:2364-2374.

Fan, M. Z. and W. C. Sauer. 1995b. Determination of apparent ileal amino acid digestibility in peas for pigs with direct difference, regression methods. Livest. Prod. Sci. 44:61-72.

Holden, P. J. and D. R. Zimmerman. 1991. Utilization of cereal grain by-products in feeding swine. In: Swine Nutrition. (Eds. E. R. Miller, D. E. Ullrey and A. J. Lewis). Butterworth, London. pp. 585-593.

Huang, S. X., W. C. Sauer and B. Marty. 2001. Ileal digestibilities of neutral detergent fiber, crude protein, and amino acids associated with neutral detergent fiber in wheat shorts for growing pigs. J. Anim. Sci. 79:2388-2396.

Huang, S. X., W. C. Sauer, B. Marty and R. T. Hardin. 1999. Amino acid digestibilities in different samples of wheat shorts for growing pigs. J. Anim. Sci. 77:2469-2477.

Jondreville, C., J. V. D. Broecke, F. Grosjean, S. V. Cauwenberghe and F. Gatel. 2000. Ileal true digestibility of amino acids in wheat milling by-products for pigs. Ann. Zootech. 49:55-65.

Kim, J. C., P. H. Simmins, B. P. Mullan and J. R. Pluske. 2005. The digestible energy value of wheat for pigs, with special reference to the post-weaned animal [review]. Anim. Feed Sci. Technol. 122:257-287.

Le Goff, G. and J. Noblet. 2001. Comparative total tract digestibility of dietary energy and nutrients in growing pigs and adult sows. J. Anim. Sci. 79:2418-2427.

Li, S., W. C. Sauer and R. T. Hardin. 1994. Effect of dietary fibre level on amino acid digestibility in young pigs. Can. J. Anim. Sci. 74:327-333.

Low, A. G. 1980. Nutrient absorption in pigs. J. Sci. Food Agric. 31:1087-1130.

NRC. 1998. Nutrient requirements of swine $10^{\text {th }}$ rev. ed. National Academy Press, Washington DC, USA.

Patience, J. F., L. G. Young and I. McMillan. 1977. Utilization of wheat shorts in swine diets. J. Anim. Sci. 45:1294-1301.

Sauer, W. C., S. C. Stothers and R. J. Parker. 1977. Apparent and true availabilities of amino acids in wheat and milling byproducts for growing pigs. Can. J. Anim. Sci. 57:775-784.

Sauvant, D., J. M. Perez and G. Tran. 2004. Tables of composition and nutritive value of feed materials. Pigs, Poultry, Cattle, Sheep, Goats, Rabbits, Horses, Fish. INRA Editions, Versailles, France.

Slominski, B. A., D. Boros, L. D. Campbell, W. Guenter and O. Jones. 2004. Wheat by-products in poultry nutrition. Part I. Chemical and nutritive composition of wheat screenings, bakery by-products and wheat mill run. Can. J. Anim. Sci. 84:421-428.

Song, G. L., D. F. Li, X. S. Piao, F. Chi and W. J. Yang. 2003. 
Apparent ileal digestibility of amino acids and the digestible and metabolizable energy content of high-oil corn varieties and its effects on growth performance of pigs. Arch. Anim. Nutr. 57:297-306.

Stein, H. H., B. Seve, M. F. Fuller, P. J. Moughan and C. F. de Lange. 2007. Invited review: Amino acid bioavailability and digestibility in pig feed ingredients: Terminology and application. J. Anim. Sci. 85:172-180.
Stein, H. H., C. F. Shipley and R. A. Easter. 1998. Technical note: A technique for inserting a T-cannula into the distal ileum of pregnant sows. J. Anim. Sci. 76:1433-1436.

Wan, H. F., W. Chen, Z. L. Qi, P. Peng and J. Peng. 2009. Prediction of true metabolizable energy from chemical composition of wheat milling by-products for ducks. Poult. Sci. 88:92-97.

Zijlstra, R. T., C. F. M. de Lange and J. F. Patience. 1999. Nutritional value of wheat for growing pigs: Chemical composition and digestible energy content. Can. J. Anim. Sci. 79:187-194. 